\title{
ANALISIS KEBUTUHAN PARKIR PADA BANK BNI CABANG KOTA PALOPO JALAN MANUNGGAL
}

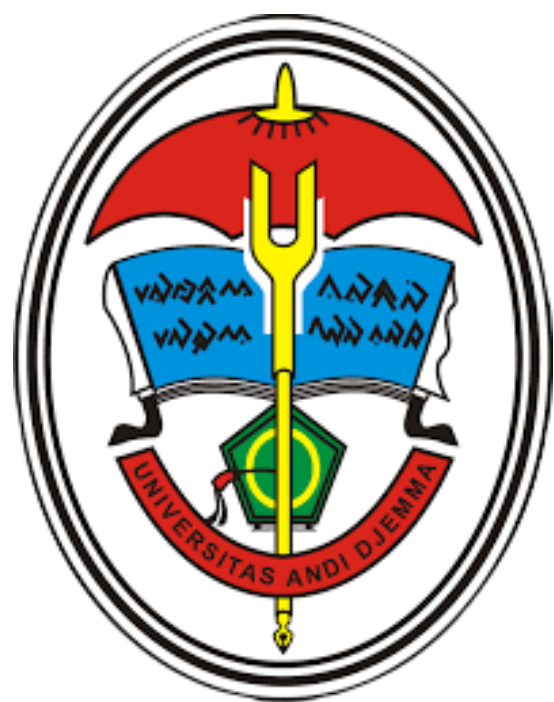

OLEH:

KELOMPOK 5

A.NUR ASMUL

NURBAETY HALIM
19.023.22.201.216

19.023.22.201.087

PROGRAM STUDI TEKNIK SIPIL

FAKULTAS TEKNIK

UNIVERSITAS ANDI DJEMMA PALOPO

2022 
A.Nur Asmul, Nurbaety Halim, Fakultas Teknik, Program Studi Teknik Sipil, Universitas Andi Djemma Palopo

\begin{abstract}
ABSTRAK
Peningkatan penggunaan fasilitas parkir di sebabkan oleh meningkatnya tingkat kepemilikan kendaraan bermotor yang disertai adanya daerah tarikan antara lain daerah perkantoran/perbankan, sekolahan, pertokoan, pusat olahraga, pusat rekreasi dan juga bangkitan yang berasal dari daerah permukiman/perumahan penduduk. Maka kebutuhan akan fasilitas parkir menjadi sangat penting mengingat fasilitas parkir merupakan bagian yang tak terpisahkan dari sistem transportasi. Tujuan penelitian ini untuk mengetahui Untuk Menganalisis jam sibuk lokasi parkiran Bank BNI cabang palopo dan Untuk Menganalisis Kebutuhan Parkir BANK BNI cabang palopo

Dalam menentukan jam sibuk lokasi parkiran yaitu dengan melakukan survei langsung di lapangan guna untuk mendapatkan hasil dari banyaknya kendaraan masuk dan keluar setiap harinya, yang dimana survei dilakukan pada jam 6.30 - 17.00 dengan interval waktu per lima belas menit selama empat hari yaitu hari kerja. Data jumlah kendaraan parkir tersebut kemudian dianalisis jam sibuknya berdasarkan banyaknya kendaraan yang keluar dan menganalisis kebutuhan parkir berdasarkan kebutuhan parkir jam puncak hasil survei.
\end{abstract}

Kata kunci : fasilitas parkir, Menganalisis jam sibuk, Menganalisis Kebutuhan Parkir 


\section{BAB 1 \\ PENDAHULUAN}

1. Latar belakang

Kebutuhan akan parkir untuk kendaraan dewasa ini telah mengalami peningkatan baik dari segi kapasitas maupun teknologi yang digunakan. Tidak dipungkiri bahwa kebutuhan akan lahan parkir sudah menjadi suatu hal yang penting dalam kehidupan sehari-hari.

Perparkiran merupakan masalah yang sering dijumpai, apalagi di daerah yang mempunyai aktivitas tinggi seperti pasar, yang sering kali menimbulkan kemacetan di jalan. Salah satu hal yang perlu dilakukan untuk meminimalkan masalah tersebut yaitu dengan analisa perparkiran pada lahan tersebut.

Dan Adapun BANK BNI cabang kota palopo yang terletak di jalan Manunggal Salah satu tempat yang akan kita survei lokasi parkirannya guna untuk mengetahui banyaknyakendaraan yang terparkir setiap hari kerja

2. Rumusan Masalah

adapun rumusan masalah makalah ini, yaitu sebagai berikut:

1. Apa yang dimaksud dengan parkiran?

2. Menganalisis jam sibuk lokasi parkiran BANK BNI cabang palopo

3. Menganalisis Kebutuhan Parkir BANK BNI cabang palopo

3. Tujuan Penulisan

Adapun tujuan penulisan adalah sebagai berikut

1. Untuk mengetahui apa dan fungsi parkiran

2. Untuk Menganalisis jam sibuk lokasi parkiran BANK BNI cabang palopo

3. Untuk Menganalisis Kebutuhan Parkir BANK BNI cabang palopo 
A.Nur Asmul, Nurbaety Halim, Fakultas Teknik, Program Studi Teknik Sipil, Universitas Andi Djemma Palopo

1. Pengertian parkir

\section{BAB II \\ LANDASAN TEORI}

Pada perencanaan terminal dan lokasi parkir yang baik adalah yang perencanaan lokasinya secara sistem jaringan mampu berperan dalam melancarkan pergerakan sistem transportasi secara keseluruhan, dengan demikian perencanaan dan pengembangannya perlu ditata dalam

satu kesatuan sistem yang terpadu (Fisu, 2018). Perencanaan sistem angkutan yang dibuat tanpa pertimbangan matang akan berdampak pada pola pergerakan, arus lalu lintas perkotaan, bahkan hingga menyebabkan kecelakaan lalu lintas (Fisu, 2019)

Kebutuhan akan parkir untuk kendaraan dewasa ini telah mengalami peningkatan baik dari segi kapasitas maupun teknologi yang digunakan. Tidak dipungkiri bahwa kebutuhan akan lahan parkir sudah menjadi suatu hal yang penting dalam kehidupan sehari-hari.

\section{CARA DAN JENIS PARKIR}

Menurut Penempatannya

1. Parkir di tepi jalan (on-street parking). Yakni parkir dengan menggunakan badan jalansebagai tempat parkir

\section{Kerugian :}

- Mengganggu lalu lintas

- Mengurangi kapasitas jalan karena adanya pengurangan lebar lajur lalu lintas

- Meningkatkan kemungkinan terjadinya kecelakaan

\section{Keuntungan:}

- Murah tanpa investasi tambahan

- Bagi pengguna tempat parkir bisa lebih dekat dan mudah Posisi parkir :

- Sejajar dengan sumbu jalan

- Tegak lurus sumbu jalan

- Membuat sudut dengan sumbu ja

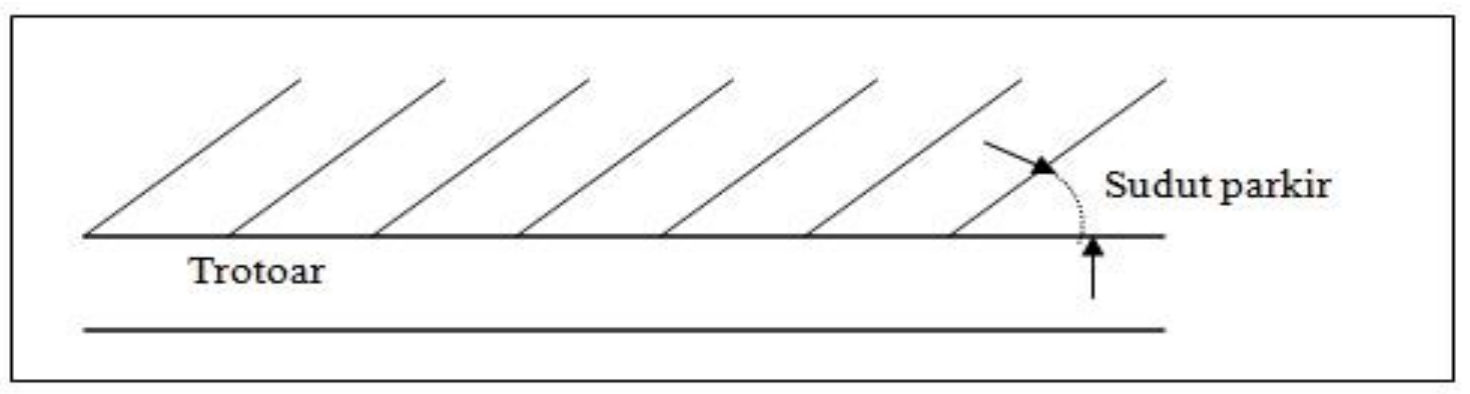

\section{Gambar Ruang Parkir Bersudut}

Sumber : Menuju lalu lintas dan angkutan jalan yang tertib, DLLAJ, 1995 
A.Nur Asmul, Nurbaety Halim, Fakultas Teknik, Program Studi Teknik Sipil, Universitas Andi Djemma Palopo

2. Parkir di luar badan jalan (off-street parking). Yakni parkir kendaraan di luar badan jalan bisadi halaman gedung perkantoran, supermarket, atau pada taman parkir.

Keuntungan :

- Tidak mengganggu lalu lintas

- Faktor keamanan lebih tinggi

Kerugian:

- Perlu biaya investasi awal yang besar.

- Bagi pengguna dirasakan kurang praktis, apalagi jika kepentingannya hanya sebentarsaja.

\section{Menurut Statusnya}

- Parkir umum, biasanya dikelola oleh pemerintah daerah.

- Parkir khusus, dikelola oleh swasta.

- Parkir darurat, diselenggarakan karena adanya kegiatan incidental.

- Taman Parkir, dikelola oleh pemerintah daerah.

- Gedung Parkir, biasanya diselenggarakan oleh pemerintah daerah dan pengelolaannyaoleh swasta.

\section{Menurut Jenis Kendaraan}

- Kendaraan tidak bermesin (sepeda)

- Sepeda motor

- Mobil

\section{Menurut Jenis Tujuan Parkir}

- Parkir penumpang : untuk kebutuhan menaikkan dan menurunkan penumpang

- Parkir barang : untuk kebutuhan bongkar muat barang

\section{Menurut Jenis Kepemilikan dan Pengoperasian}

- Milik swasta dan dikelola oleh swasta

- Milik pemerintah daerah dan dikelola oleh pemda

- Milik pemerintah daerah dan dikelola oleh swasta 
A.Nur Asmul, Nurbaety Halim, Fakultas Teknik, Program Studi Teknik Sipil, Universitas Andi Djemma Palopo

\section{BAB III}

1. Gambaran Umum Lokasi

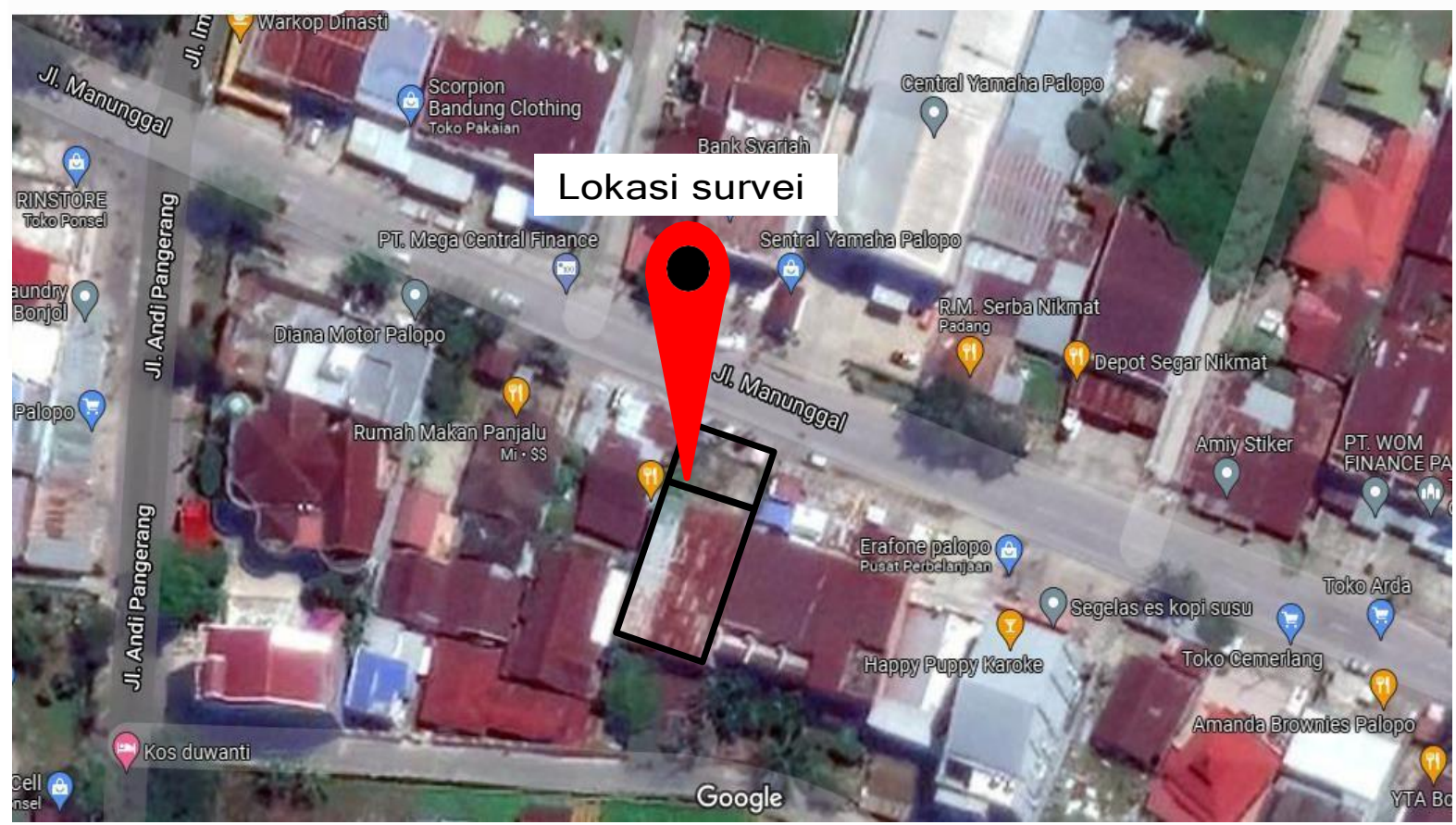

2. Hasil Survei

\section{FORMULIR SURVEI PERHITUNGAN PARKIRAN}

\begin{tabular}{|c|c|c|c|c|c|}
\hline Lokasi & : & $\begin{array}{l}\text { BANK BNI CABANG } \\
\text { PALOPO }\end{array}$ & Jam Mulai & : & 6.30 \\
\hline Tanggal & : & Senin, 13 Desember 2021 & Jam berakhir & : & 17.00 \\
\hline Petugas Survei & : & Kelompok V (lima) & & & \\
\hline
\end{tabular}

\begin{tabular}{|c|c|c|c|c|}
\hline \multirow{2}{*}{ WAKTU } & \multicolumn{2}{|c|}{ Mobil } & \multicolumn{2}{|c|}{ Motor } \\
\hline & Masuk & Keluar & Masuk & Keluar \\
\hline $6.30-6.45$ & & & & \\
\hline $6.45-7.00$ & 1 & & & \\
\hline $7.00-7.15$ & & & & \\
\hline $7.15-7.30$ & & & 2 & \\
\hline $7.30-7.45$ & 1 & & & \\
\hline $7.45-8.00$ & & 1 & 3 & 2 \\
\hline $8.00-8.15$ & & & 5 & 1 \\
\hline $8.15-8.30$ & & 1 & 15 & 5 \\
\hline $8.30-8.45$ & & 1 & 7 & 10 \\
\hline $8.45-9.00$ & & & 12 & 3 \\
\hline $9.00-9.15$ & & & 15 & 14 \\
\hline $9.15-9.30$ & 3 & 2 & 15 & 8 \\
\hline
\end{tabular}


A.Nur Asmul, Nurbaety Halim, Fakultas Teknik, Program Studi Teknik Sipil, Universitas Andi Djemma Palopo

\begin{tabular}{|c|c|c|c|c|}
\hline $9.30-9.45$ & & & 11 & 9 \\
\hline $9.45-10.00$ & & 1 & 10 & 7 \\
\hline $10.00-10.15$ & & 1 & 13 & 5 \\
\hline $10.15-10.30$ & 2 & & 8 & 6 \\
\hline $10.30-10.45$ & 1 & 2 & 11 & 9 \\
\hline $10.45-11.00$ & 1 & 1 & 13 & 14 \\
\hline $11.00-11.15$ & & 2 & 11 & 10 \\
\hline $11.15-11.30$ & 1 & & 14 & 20 \\
\hline $11.30-11.45$ & & & 12 & 15 \\
\hline $11.45-12.00$ & & 2 & 8 & 5 \\
\hline $12.00-12.15$ & 1 & 1 & 3 & 2 \\
\hline $12.15-12.30$ & & & 2 & \\
\hline $12.30-12.45$ & & & & 7 \\
\hline $12.45-13.00$ & & & 9 & 6 \\
\hline $13.00-13.15$ & & & 5 & 4 \\
\hline $13.15-13.30$ & & & 6 & 10 \\
\hline $13.30-13.45$ & & & 8 & 9 \\
\hline $13.45-14.00$ & 1 & & 8 & 10 \\
\hline $14.00-14.15$ & 3 & 2 & 17 & 8 \\
\hline $14.15-14.30$ & 1 & & 8 & 9 \\
\hline $14.30-14.45$ & 2 & 2 & 8 & 13 \\
\hline $14.45-15.00$ & & & 3 & 7 \\
\hline $15.00-15.15$ & 1 & 3 & 5 & 8 \\
\hline $15.15-15.30$ & 1 & 3 & 9 & 11 \\
\hline $15.30-15.45$ & 1 & & 4 & 13 \\
\hline $15.45-16.00$ & 1 & & 3 & 6 \\
\hline $16.00-16.15$ & & & 5 & 7 \\
\hline $16.15-16.30$ & 3 & & 1 & 8 \\
\hline $16.30-16.45$ & & 2 & 6 & 6 \\
\hline $16.45-17.00$ & & & 6 & 6 \\
\hline
\end{tabular}


A.Nur Asmul, Nurbaety Halim, Fakultas Teknik, Program Studi Teknik Sipil, Universitas Andi Djemma Palopo

\section{FORMULIR SURVEI PERHITUNGAN PARKIRAN}

\begin{tabular}{|c|c|c|c|c|c|}
\hline Lokasi & : & BANK BNI CABANG PALOPO & Jam Mulai & : & 6.30 \\
\hline Tanggal & $0^{\circ}$ & Selasa, 14 Desember 2021 & Jam berakhir & : & 17.00 \\
\hline Petugas Survei & : & Kelompok V (lima) & & & \\
\hline
\end{tabular}

\begin{tabular}{|c|c|c|c|c|}
\hline \multirow{2}{*}{ WAKTU } & \multicolumn{2}{|c|}{ Mobil } & \multicolumn{2}{|c|}{ Motor } \\
\hline & Masuk & Keluar & Masuk & Keluar \\
\hline $6.30-6.45$ & & & 1 & \\
\hline $6.45-7.00$ & & & 1 & \\
\hline $7.00-7.15$ & & & 3 & \\
\hline $7.15-7.30$ & & & & \\
\hline $7.30-7.45$ & 1 & & & \\
\hline $7.45-8.00$ & & & 3 & 1 \\
\hline $8.00-8.15$ & 1 & & 8 & 1 \\
\hline $8.15-8.30$ & 1 & & 18 & 7 \\
\hline $8.30-8.45$ & & 2 & 4 & 5 \\
\hline $8.45-9.00$ & & & 8 & 8 \\
\hline $9.00-9.15$ & & & 11 & 14 \\
\hline $9.15-9.30$ & 2 & 1 & 10 & 8 \\
\hline $9.30-9.45$ & & & 4 & 7 \\
\hline $9.45-10.00$ & & 1 & 14 & 8 \\
\hline $10.00-10.15$ & & & 12 & 4 \\
\hline $10.15-10.30$ & 3 & & 19 & 9 \\
\hline $10.30-10.45$ & & 2 & 11 & 9 \\
\hline $10.45-11.00$ & 1 & 1 & 13 & 14 \\
\hline $11.00-11.15$ & & 1 & 10 & 18 \\
\hline $11.15-11.30$ & 1 & & 9 & 23 \\
\hline $11.30-11.45$ & & & 14 & 15 \\
\hline $11.45-12.00$ & & 2 & 13 & 5 \\
\hline $12.00-12.15$ & 1 & 1 & 2 & 3 \\
\hline $12.15-12.30$ & & & 1 & \\
\hline $12.30-12.45$ & & & 3 & 5 \\
\hline $12.45-13.00$ & 3 & & 10 & 5 \\
\hline $13.00-13.15$ & & 2 & 7 & 7 \\
\hline $13.15-13.30$ & & & 3 & 5 \\
\hline $13.30-13.45$ & 1 & & 9 & 9 \\
\hline $13.45-14.00$ & & & 14 & 8 \\
\hline $14.00-14.15$ & 1 & 2 & 5 & 6 \\
\hline $14.15-14.30$ & 1 & & 17 & 13 \\
\hline $14.30-14.45$ & 2 & 2 & 8 & 17 \\
\hline $14.45-15.00$ & & & 11 & 8 \\
\hline $15.00-15.15$ & 1 & 3 & 4 & 6 \\
\hline $15.15-15.30$ & & 1 & 7 & 10 \\
\hline $15.30-15.45$ & 1 & 1 & 4 & 16 \\
\hline
\end{tabular}


A.Nur Asmul, Nurbaety Halim, Fakultas Teknik, Program Studi Teknik Sipil, Universitas Andi Djemma Palopo

\begin{tabular}{|r|r|r|r|r|}
\hline $15.45-16.00$ & & & 3 & 7 \\
\hline $16.00-16.15$ & & & 9 & 11 \\
\hline $16.15-16.30$ & 2 & & 8 & 14 \\
\hline $16.30-16.45$ & & 1 & 3 & 7 \\
\hline $16.45-17.00$ & & & 5 & 5 \\
\hline
\end{tabular}

\section{FORMULIR SURVEI PERHITUNGAN PARKIRAN}

\begin{tabular}{|c|c|c|c|c|c|}
\hline Lokasi & : & BANK BNI CABANG PALOPO & Jam Mulai & : & 6.30 \\
\hline Tanggal & . & Rabu, 15 Desember 2021 & Jam berakhir & & 17.00 \\
\hline Petugas Survei & : & Kelompok V (lima) & & & \\
\hline
\end{tabular}

\begin{tabular}{|c|c|c|c|c|}
\hline \multirow{2}{*}{ WAKTU } & \multicolumn{2}{|c|}{ Mobil } & \multicolumn{2}{|c|}{ Motor } \\
\hline & Masuk & Keluar & Masuk & Keluar \\
\hline \multicolumn{5}{|l|}{$6.30-6.45$} \\
\hline $6.45-7.00$ & 1 & & 1 & \\
\hline $7.00-7.15$ & 1 & & & \\
\hline $7.15-7.30$ & & & 1 & \\
\hline $7.30-7.45$ & 1 & & 1 & \\
\hline $7.45-8.00$ & & 1 & 4 & 2 \\
\hline $8.00-8.15$ & & & 7 & 1 \\
\hline $8.15-8.30$ & & 1 & 12 & 5 \\
\hline $8.30-8.45$ & 1 & 1 & 11 & 11 \\
\hline $8.45-9.00$ & 1 & & 7 & 7 \\
\hline $9.00-9.15$ & & 1 & 17 & 12 \\
\hline $9.15-9.30$ & & 1 & 13 & 9 \\
\hline $9.30-9.45$ & & & 10 & 7 \\
\hline $9.45-10.00$ & & & 9 & 9 \\
\hline $10.00-10.15$ & 2 & & 8 & 13 \\
\hline $10.15-10.30$ & & 1 & 14 & 11 \\
\hline $10.30-10.45$ & & 1 & 8 & 8 \\
\hline $10.45-11.00$ & 3 & 1 & 9 & 9 \\
\hline $11.00-11.15$ & & & 12 & 11 \\
\hline $11.15-11.30$ & & & 9 & 18 \\
\hline $11.30-11.45$ & 1 & & 11 & 3 \\
\hline $11.45-12.00$ & & 1 & 7 & 7 \\
\hline $12.00-12.15$ & 2 & & 4 & 2 \\
\hline $12.15-12.30$ & & 1 & 1 & 1 \\
\hline $12.30-12.45$ & & & 1 & 9 \\
\hline $12.45-13.00$ & 1 & & 7 & 4 \\
\hline $13.00-13.15$ & & & 6 & 5 \\
\hline $13.15-13.30$ & & & 9 & 8 \\
\hline $13.30-13.45$ & & 1 & 12 & 5 \\
\hline $13.45-14.00$ & 1 & & 7 & 6 \\
\hline
\end{tabular}


A.Nur Asmul, Nurbaety Halim, Fakultas Teknik, Program Studi Teknik Sipil, Universitas Andi Djemma Palopo

\begin{tabular}{|r|r|r|r|r|}
\hline $14.00-14.15$ & 1 & & 13 & 4 \\
\hline $14.15-14.30$ & 2 & 2 & 9 & 10 \\
\hline $14.30-14.45$ & 1 & & 7 & 11 \\
\hline $14.45-15.00$ & 1 & 2 & 4 & 7 \\
\hline $15.00-15.15$ & & & 2 & 8 \\
\hline $15.15-15.30$ & 1 & & 2 & 12 \\
\hline $15.30-15.45$ & 1 & & 6 & 13 \\
\hline $15.45-16.00$ & 1 & 1 & 3 & 7 \\
\hline $16.00-16.15$ & & 1 & 1 & 7 \\
\hline $16.15-16.30$ & & & 1 & 3 \\
\hline $16.30-16.45$ & & 1 & 1 & 1 \\
\hline $16.45-17.00$ & & 1 & 4 & 5 \\
\hline
\end{tabular}

\section{FORMULIR SURVEI PERHITUNGAN PARKIRAN}

\begin{tabular}{|c|c|c|c|c|c|}
\hline Lokasi & : & BANK BNI CABANG PALOPO & Jam Mulai & $:$ & 6.30 \\
\hline Tanggal & : & Kamis, 16 Desember 2021 & Jam berakhir & & 17.00 \\
\hline Petugas Survei & : & Kelompok V (lima) & & & \\
\hline
\end{tabular}

\begin{tabular}{|c|c|c|c|c|}
\hline \multirow{2}{*}{ WAKTU } & \multicolumn{2}{|c|}{ Mobil } & \multicolumn{2}{|c|}{ Motor } \\
\hline & Masuk & Keluar & Masuk & Keluar \\
\hline $6.30-6.45$ & & & & \\
\hline $6.45-7.00$ & & & & \\
\hline $7.00-7.15$ & & & & \\
\hline $7.15-7.30$ & & & 2 & 1 \\
\hline $7.30-7.45$ & 1 & & 2 & \\
\hline $7.45-8.00$ & & & 7 & 1 \\
\hline $8.00-8.15$ & 1 & & 5 & 1 \\
\hline $8.15-8.30$ & 1 & 2 & 13 & 7 \\
\hline $8.30-8.45$ & & 1 & 9 & 9 \\
\hline $8.45-9.00$ & & & 12 & 8 \\
\hline $9.00-9.15$ & & 1 & 13 & 11 \\
\hline $9.15-9.30$ & & 1 & 12 & 7 \\
\hline $9.30-9.45$ & & & 15 & 6 \\
\hline $9.45-10.00$ & 2 & 1 & 11 & 19 \\
\hline $10.00-10.15$ & 1 & 1 & 17 & 7 \\
\hline $10.15-10.30$ & 1 & & 9 & 9 \\
\hline $10.30-10.45$ & & & 18 & 5 \\
\hline $10.45-11.00$ & 1 & & 12 & 8 \\
\hline $11.00-11.15$ & 1 & & 8 & 11 \\
\hline $11.15-11.30$ & & 1 & 11 & 13 \\
\hline $11.30-11.45$ & & 1 & 9 & 15 \\
\hline $11.45-12.00$ & & & 7 & 7 \\
\hline $12.00-12.15$ & & 1 & 9 & 8 \\
\hline
\end{tabular}


A.Nur Asmul, Nurbaety Halim, Fakultas Teknik, Program Studi Teknik Sipil, Universitas Andi Djemma Palopo

\begin{tabular}{|c|c|c|c|c|}
\hline $12.15-12.30$ & & & 9 & 9 \\
\hline $12.30-12.45$ & 1 & 1 & 1 & 1 \\
\hline $12.45-13.00$ & & & 8 & 2 \\
\hline $13.00-13.15$ & & & 15 & 6 \\
\hline $13.15-13.30$ & & & 9 & 11 \\
\hline $13.30-13.45$ & & 1 & 4 & 9 \\
\hline $13.45-14.00$ & 1 & & 3 & 9 \\
\hline $14.00-14.15$ & & & 11 & 5 \\
\hline $14.15-14.30$ & 1 & & 7 & 7 \\
\hline $14.30-14.45$ & 1 & 1 & 6 & 12 \\
\hline $14.45-15.00$ & & & 9 & 8 \\
\hline $15.00-15.15$ & 1 & 2 & 4 & 9 \\
\hline $15.15-15.30$ & 2 & 2 & 8 & 3 \\
\hline $15.30-15.45$ & 1 & & 5 & 15 \\
\hline $15.45-16.00$ & 1 & 1 & 7 & 7 \\
\hline $16.00-16.15$ & & & 7 & 7 \\
\hline $16.15-16.30$ & & & 9 & 15 \\
\hline $16.30-16.45$ & 1 & 1 & 1 & 9 \\
\hline $16.45-17.00$ & & & 4 & 11 \\
\hline
\end{tabular}

3. Pengoalahan Data Survei

a. Menganalisis jam sibuk

- Senin 13 November 2021

\section{SURVEI PARKIRAN}

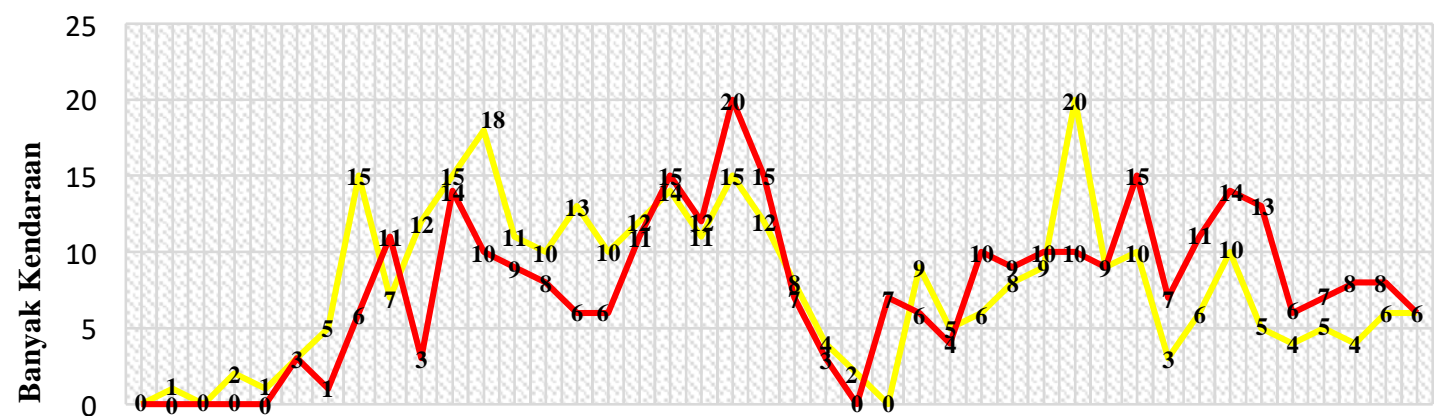

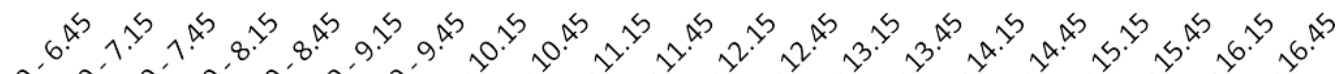

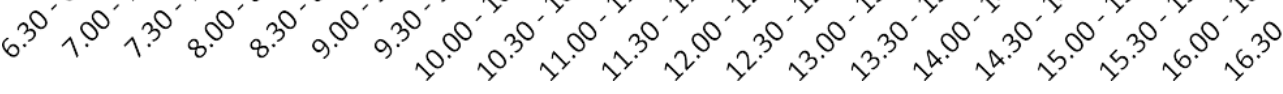

waktu 
A.Nur Asmul, Nurbaety Halim, Fakultas Teknik, Program Studi Teknik Sipil, Universitas Andi Djemma Palopo

- $\quad$ Selasa 14 November 2021

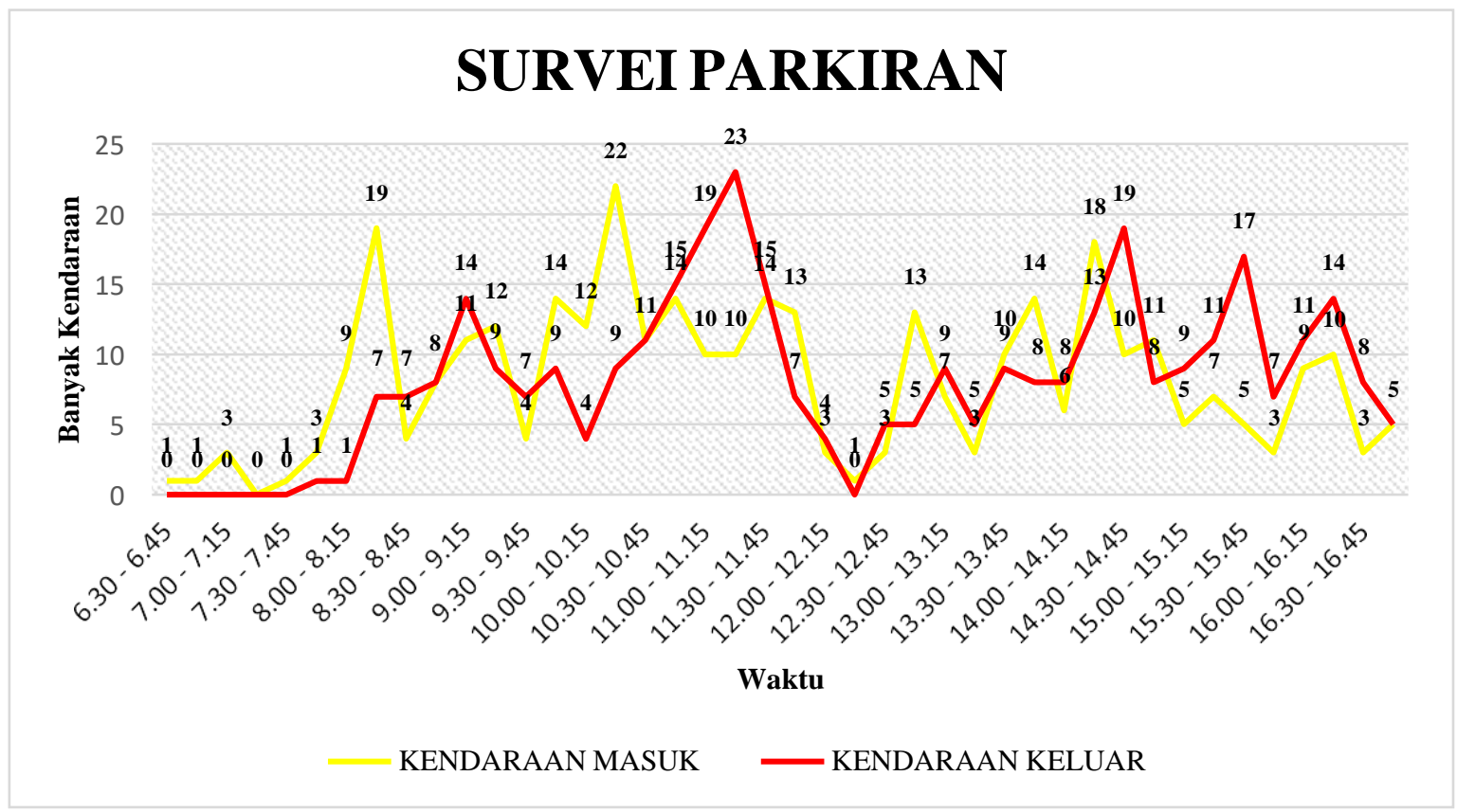

- $\quad$ Rabu 15 November 2021

\section{SURVEI PARKIRAN}

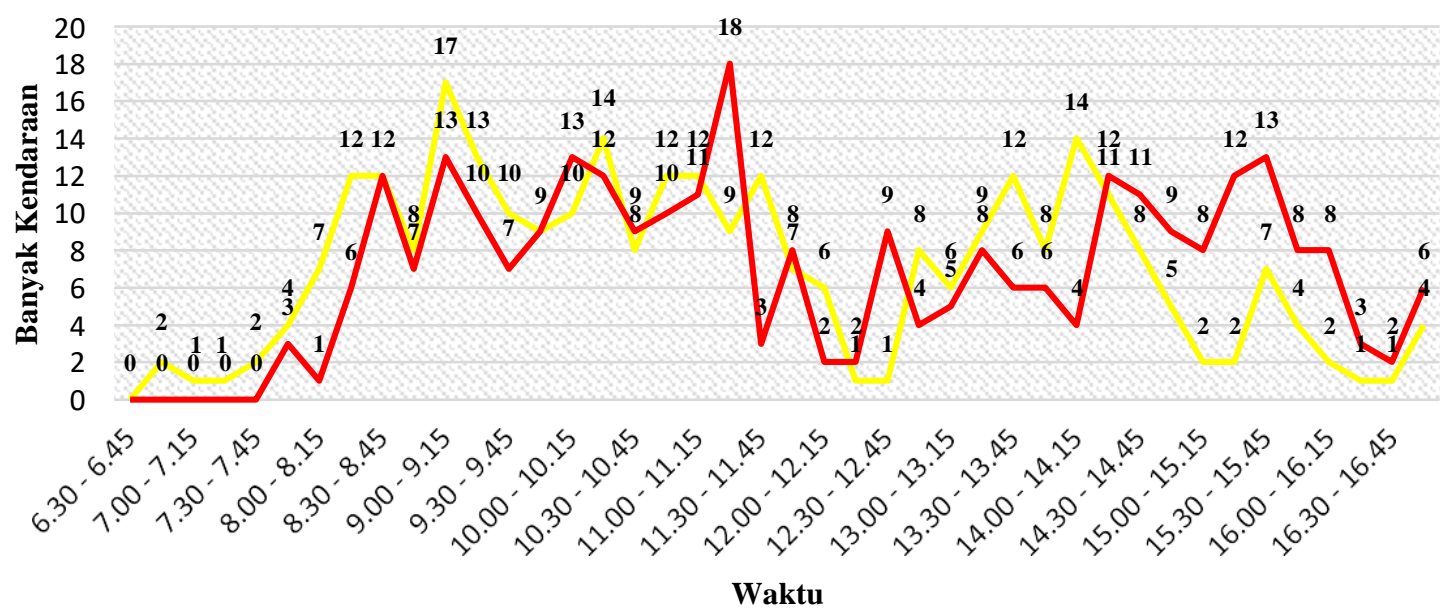


- $\quad$ Rabu 15 November 2021

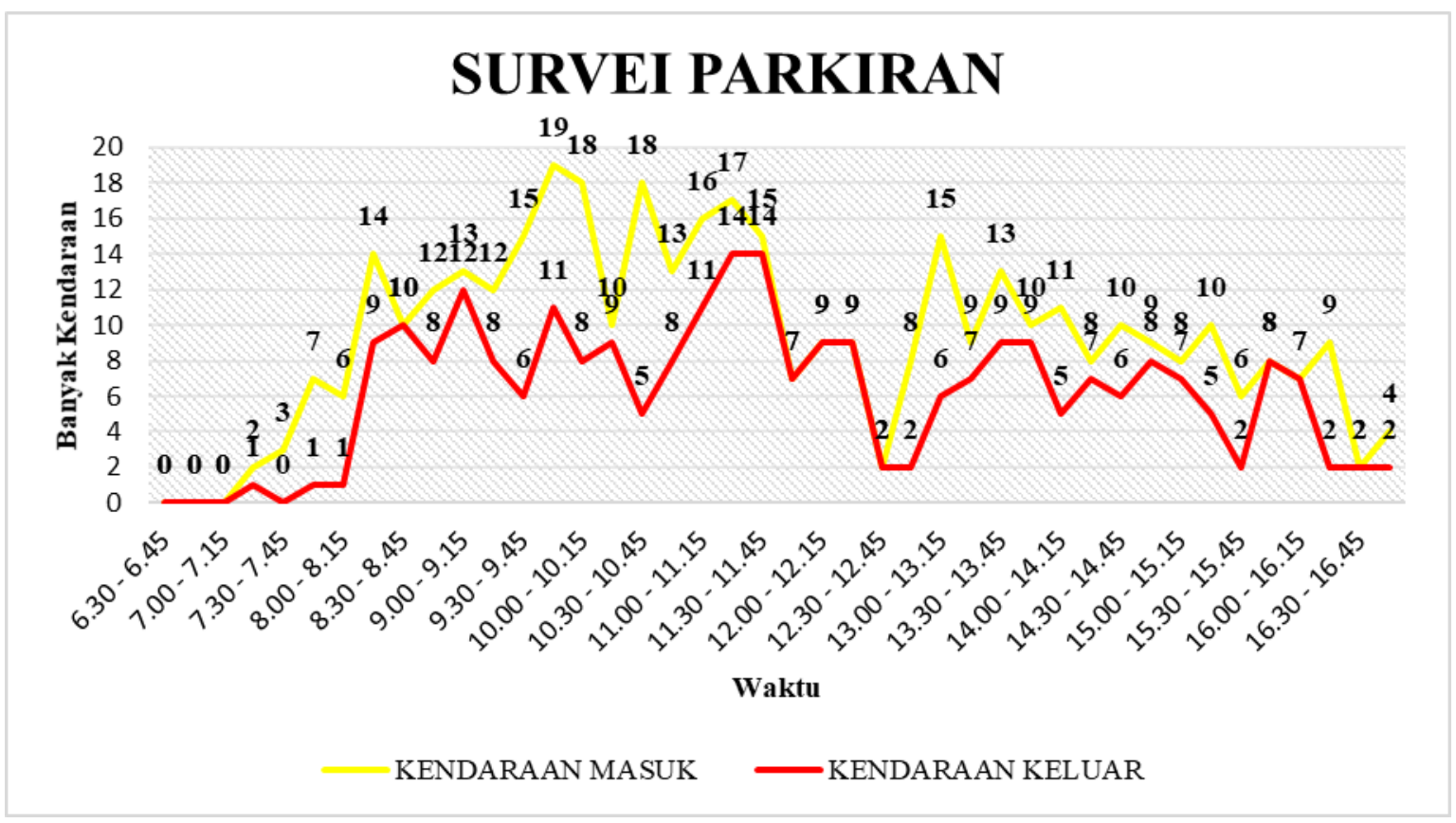

b. Kesimpulan

1. Pada hari Senin pukul 6.30 - 6.45 Sampai dengan pukul 16.30 16.45 terpantau kepadatan kendaraan yang terparkir di BANK BNI cabang palopo berbeda dari setiap waktunya, dan kesimpulan dari hasil survei dapat terlihat bahwa banyaknya kendaraanyang masuk dan terparkir berada pada jam 9.15 - 9.30 dan banyaknya kendaraan yang keluar berada pada jam 14.00 - 14.15

2. Pada hari Selasa pukul 6.30 - 6.45 Sampai dengan pukul 16.30 16.45 terpantau kepadatan kendaraan yang terparkir di BANK BNI cabang palopo berbeda dari setiap waktunya, dan kesimpulan dari hasil survei dapat terlihat bahwa banyaknya kendaraanyang masuk dan terparkir berada pada jam 10.15 - 10.30 dan banyaknya kendaraan yang keluar berada pada jam 11.15 - 11.30

3. Pada hari Rabu pukul 6.30 - 6.45 Sampai dengan pukul 16.30 16.45 terpantau kepadatan kendaraan yang terparkir di BANK BNI cabang palopo berbeda dari setiap waktunya, dan kesimpulan dari hasil survei dapat terlihat bahwa banyaknya kendaraanyang masuk dan terparkir berada pada jam 10.00 - 10.15 dengan 10.30 - 10.45 dan banyaknya kendaraan yang keluar berada pada jam 11.15 11.30 dengan $11.30-11.45$

4. Pada hari Selasa pukul 6.30 - 6.45 Sampai dengan pukul 16.30 16.45 terpantau kepadatan kendaraan yang terparkir di BANK BNI cabang palopo berbeda dari setiap waktunya, dan kesimpulan dari hasil survei dapat terlihat bahwa banyaknya kendaraanyang masuk dan terparkir berada pada jam 10.15 - 10.30 dan banyaknya kendaraan yang keluar berada pada jam 11.15 - 11.35 
A.Nur Asmul, Nurbaety Halim, Fakultas Teknik, Program Studi Teknik Sipil, Universitas Andi Djemma Palopo

4. Menganalisis Kebutuhan Parkir

Berdasarkan Hasil survei pengolahan data dan jam puncak hasil survei dapat dilihat bahwa 1 jam paling sibuk terjadi pada hari kamis jam $09.45-10.45$ dengan banyaknya kendaraan yaitu 65 kendaraan dimana banyaknya kendaraan roda 2 yaitu 61 kendaraan dan roda 4 yaitu 4 kendaraan yang terparkir dalam waktu satu jam diparkiran di bank BNI cabang palopo dan dapat kita simpulkan bahwa kebutuhan parkir Yng tersedia di BANK BNI cabang kota Palopo yaitu:

Roda $2=61$ kendaraan

Roda $4=4$ kendaraan 
A.Nur Asmul, Nurbaety Halim, Fakultas Teknik, Program Studi Teknik Sipil, Universitas Andi Djemma Palopo

\section{BAB IV \\ KESIMPULAN}

Kesimpulan yang dipadat pada hasil Perhitungan survei Parkiran pada lokasi Bank BNI Cabang Kota Palopo yang terletak pada jalan Manunggal adalah Fasilitas tempat parkir memegang peranan penting bagi kelancaran kegiatan di suatu kantor atau tempat tertentu, terlihat jelas bahwa parkiran di kantor BANK BNI Cabang Kota Palopo belum cukup memadai, dengan parkiran yang kurang mengakibatkan banyak kendaraan yang mengambil Sebagian bahu jalan sebagai tempat untuk memarkirkan kendaraannya dan juga sering mengakibatkan kemacetan di depan kantor BANK BNI cabang kota palopo. 
A.Nur Asmul, Nurbaety Halim, Fakultas Teknik, Program Studi Teknik Sipil, Universitas Andi Djemma Palopo

\section{Daftar Pustaka}

Fisu, A. A. (2018). Analisis Lokasi Pada Perencanaan Terminal Topoyo Mamuju Tengah. PENA TEKNIK: Jurnal IImiah IImu-IImu Teknik, 3(1), 1-12.

Fisu, A. A. (2019). Tinjauan Kecelakaan lalu Lintas Antar Wilayah Pada Jalan Trans Provinsi Sulawesi Selatan. PENA TEKNIK: Jurnal IImiah Ilmu-ilmu Teknik, 4(1), 53-65.

Arishandi, N. G., Suthanaya, P. A., \& Wedagama, D. M. P. (2017). ANALISIS KARAKTERISTIK DAN KEBUTUHAN PARKIR TERMINAL KARGO DI KOTA DENPASAR. Jurnal Spektran. https://doi.org/10.24843/SPEKTRAN.2017.v05.i01.p09

BUDHI W, A., \& FERNANDA S, T. (2006). ANALISA KEBUTUHAN RUANG PARKIR JAVA SUPERMALL SEMARANG.

Gea, M. (2013). Analisis Kinerja Ruas Jalan Akibat Parkir Pada Badan Jalan (Studi Kasus: Pasar dan Pertokoan di Jalan Besar Delitua). Jurnal Teknik Sipil USU, 1(2).

HANDAYANI, Y. S. R. I., Suwandono, D., \& Manulang, O. R. (2002). ANALISIS KARAKTERISTIK PARKIR KHUSUS TERHADAP INTENSITAS PARKIR DI KAWASAN SIMPANG LIMA. Universitas Diponegoro.

Jaya Wikrama, A. A. (2010). Analisis Karakteristik dan Kebutuhan Parkir di Pasar Kreneng. Jurnal IImiah Teknik Sipil, 14(2).

Kasan, M. (2010). Model Kebutuhan Satuan Ruang Parkir Usaha Perdagangan Pakaian di Kota Palu. SMARTek, 8(1).

Limantara, A. D., Candra, A. I., \& Mudjanarko, S. W. (2017). MANAJEMEN DATA LALU LINTAS KENDARAAN BERBASIS SISTEM INTERNET CERDAS UJICOBA IMPLEMENTASI DI LABORATORIUM UNIVERSITAS KADIRI. Prosiding Semnastek.

Limantara, A. D., Purnomo, Y. C. S., \& Mudjanarko, S. W. (2017). PEMODELAN SISTEM PELACAKAN LOT PARKIR KOSONG BERBASIS SENSOR ULTRASONIC DAN INTERNET OF THINGS (IOT) PADA LAHAN PARKIR DILUAR JALAN. Prosiding Semnastek.

Mudjanarko, S. W., \& Sulistio, H. (2013). Behaviour Model of Motor Cycle User in Selecting Parking Location (Case study in Surabaya City of Indonesia). Journal of Basic and Applied Scientific Research (JBASR), 3, 842â€"846.

Perhubungan, D. (1996). Keputusan Direktur Jendral perhubungan Darat Tentang Pedoman Teknis Penyelenggaraan Fasilitas Parkir. Jakarta.

Purbanto, I., \& Raka, G. (2012). Karakteristik Parkir Pinggir Jalan (On Street Parking) dan Pengaruhnya Terhadap Kinerja Ruas Jalan. Jurnal IImiah Teknik Sipil. Vol, 16.

Sudirahardjo, R. (2003). Analisis Kebutuhan Ruang Parkir Di Pasar Bandarjo Ungaran. Magister Teknik Sipil. 
Sulistio, H., \& Mudjanarko, S. W. (2011). SCENARIO OF PARKING DISTRIBUTION WITH INTELLIGENT TRANSPORTATION SYSTEMS. International Journal of Academic Research, 3(2).

Supriono, J., \& Mudjanarko, S. W. (2016). Evaluasi Kinerja Parkir Di Rsu Haji Surabaya. E-Jurnal Spirit Pro Patria, 1(2).

Suthanaya, P. A. (2010). Analisis Karakteristik Dan Kebutuhan Ruang Parkir Pada Pusat Perbelanjaan Di Kabupaten Badung. Jurnal Ilmiah Teknik Sipil, 14(1).

Suwardi, S. (2009). ANALISIS KARAKTERISTIK DAN DAMPAK PARKIR TERHADAP LALULINTAS, DI SOLO GRAND MALL SURAKARTA. Jurnal Teknik Sipil Universitas Atma Jaya Yogyakarta, 8(2), pp-105.

Warpani, S. (1992). Kependudukan dan Pembangunan Daerah di Indonesia. Journal of Regional and City Planning, 3(3), 10â€"15.

Yulmida, D., Mudjanarko, S. W., Setiawan, M. I., \& Limantara, A. D. (2017). Analisis Kinerja Parkir Sepanjang Jalan Walikota Mustajab Surabaya. U KARST, 1(1). 